\title{
The elytro-tergal stridulatory apparatus of the genus Bondarius Rosado-Neto (Coleoptera, Curculionidae)
}

\author{
Germano H. Rosado-Neto ${ }^{1}$ \& Geane Brizzola dos Santos²
}

\begin{abstract}
1Departamento de Zoologia, Universidade Federal do Paraná, Caixa Postal 19020, 81530-980 Curitiba-PR, Brazil. rosadoneto@ufpr.br ${ }^{2}$ Programa Nacional de Pós Doutorado, Pós Graduação em Ecologia e Conservação da Biodiversidade, Universidade Federal de Mato Grosso, Av Fernando Correa da Costa s/n, 78060-900 Cuiabá-MT, Brazil. Fellowship CAPES. gbrizola@yahoo.com.br
\end{abstract}

\begin{abstract}
The elytro-tergal stridulatory apparatus of the genus Bondarius Rosado-Neto (Coleoptera, Curculionidae). The elytrotergal stridulatory organ that occurs in Bondarius Rosado-Neto, 2006 a genus of the tribe Sternechini (Curculionidae, Molytinae) is described and illustrated. The stridulatory apparatus is present both in male and female and is composed by the file, a narrow elevated carina which is transversely multistriate located at the apical third of the internal side near the suture of left elytron, and by the plectrum, a narrow striate area located transversely at the dorso-apical margin of the abdominal tergite 7.
\end{abstract}

KEYWORDS. Morphology; stridulation apparatus; weevils.

RESUMO. Aparelho estridulatório élitro-tergal do gênero Bondarius Rosado-Neto (Coleoptera, Curculionidae). O aparelho estridulatório do tipo élitro-tergal que ocorre em Bondarius Rosado-Neto, 2006 um gênero da tribo Sternechini (Curculionidae, Molytinae) é descrito e ilustrado. O aparelho estridulatório presente em machos e fêmeas é composto pelo file, uma carena multiestriada, estreita e elevada, localizada transversalmente no terço apical do élitro esquerdo, na margem interna, próximo a sutura elitral, e pelo plectrum, uma área estreita e estriada localizada transversalmente na margem dorso-apical do tergito abdominal 7.

PALAVRAS-CHAVE. Aparelho de estridulação; Curculionidae; morfologia.

The mechanism of stridulation is one of the most known methods of sound production in insects, specially observed in some orders such as Heteroptera, Orthoptera and Coleoptera. An elytro-tergal stridulatory organ is present in different families of Coleoptera, including weevils, and it is constituted by structures on the elytral underside and on the abdominal tergite 7 that are rubbed one against another. In this case, Dumortier (1963) defined the "plectrum" as being the striking area, and "pars stridens" or "file" as the rubbed area.

Several authors (among them, Mampe \& Neuzing 1966; Gibson 1967; Claridge 1968; Harman \& Harman 1972; Jansson \& Selander 1977 and recently Gaiger \& Vanin 2006) have described some kind of stridulatory apparatus (elytro-femoral or elytro-tergal) in weevils and recorded that stridulation sound were related to aggressiveness and precopulatory behavior.

A complete revision of the elytro-tergal stridulation in Curculionoidea was made by Lyal \& King (1996) studying the morphology, distribution and homology of the stridulatory structures. The authors (l.c.) also presented a review of the other known stridulatory systems in the superfamily. The aim of these authors was to get subsidies to investigate the phylogenetic implications within weevils. Lyal \& King (1996: 771) listed two species of Sternechini (a male of Sternechus continuus Champion, and a male of $S$. tuberculatus Boheman) as weevils without an elytral "file". However, Rosado-Neto
(1996) during the process of revision of the tribe Sternechini observed that besides $S$. tuberculatus, several others species of Sternechus have also a similar elytro-tergal structure of "file" and "plectrum". These species were accommodated by Rosado-Neto (2006) in a new genus nominated Bondarius. We presume that the lapse committed by Lyal \& King (1996) is on the species observed. Probably, they have examined a male specimen of $S$. tuberosus Boheman instead of $S$. tuberculatus.

Observations were made using a stereomicroscope with the magnification up to $\mathrm{x} 50$. The illustrations (figs. $1 \mathrm{~A}-\mathrm{B}$, $2 \mathrm{~A}-\mathrm{B}$ ) were taken from a male of Bondarius tuberculatus in a scanning electron microscope Philips (SEM 100-505) at the "Centro de Microscopia Eletrônica da Universidade Federal do Paraná (Curitiba, PR)". The structures of the stridulatory apparatus were observed in the following eight species (males and females) cited by Rosado-Neto (2006) (number of specimens examined in parenthesis): Bondarius breyeri (Brèthes, 1910) (06 males and 03 females); $B$. fuscoaeneus (Boheman, 1843) (50 males and 31 females); B. nitidus (Champion, 1902) (13 males and 16 females); $B$. pectoralis (Suffrian, 1872) (01 male and 01 female); $B$. spinipes (Champion, 1902) (10 males and 14 females); $B$. sublaevicollis (Hustache, 1939) (21 males and 21 females); B. subrufus (Fiedler, 1936) (22 males and 22 females) e $B$. tuberculatus (Boheman, 1836) (37 males and 32 females). All 


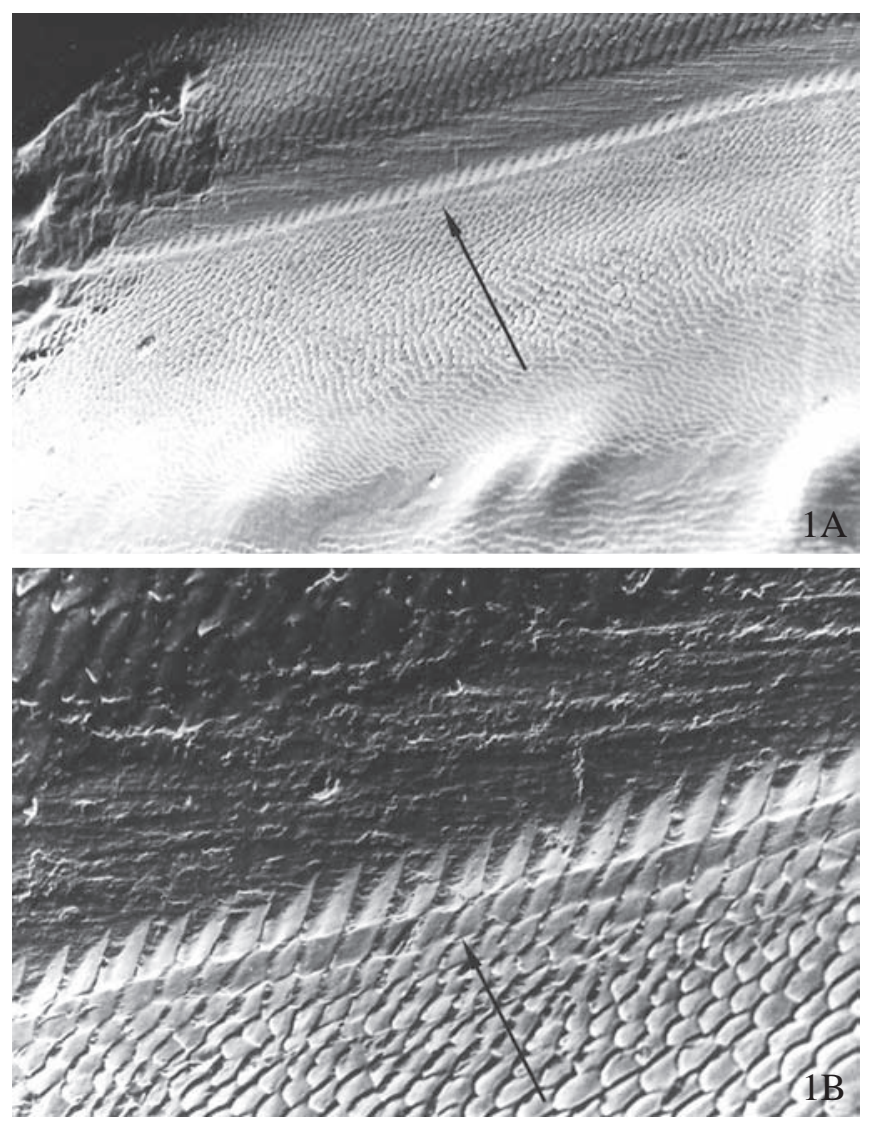

Fig 1. Bondarius tuberculatus: internal view of apical third of left elytron, showing the striated carina (file), A) 194,2x; B) 654,5x.

these specimens that belong to several collections of the world will be listed during the systematic revision of Bondarius which is in its conclusion phase.

The stridulatory apparatus in Bondarius comprises a narrow elevated carina which is transversely multistriate, located internally on the apical third of the left elytron near suture (file, figs. 1A-B), and by a narrow striate area located transversely at the dorso-apical margin of the abdominal tergite 7 (plectrum, figs. $2 \mathrm{~A}-\mathrm{B}$ ). These structures are present both in male and female.

No living specimens were examined. However in dried specimens previously hydrated it was observed that a single handmade movement by pressure of the abdomen against the internal apex of the elytron produced a scraping sound. Probably these structures are part of a stridulatory apparatus, but only future observations in living specimens will confirm this fact.

Acknowledgment. To Dr. Luís Amilton Foerster for reviewing the manuscript and for the correction of the English text.

\section{REFERENCES}

Claridge, L. C. 1968. Sound production in species of Rhynchaenus (=
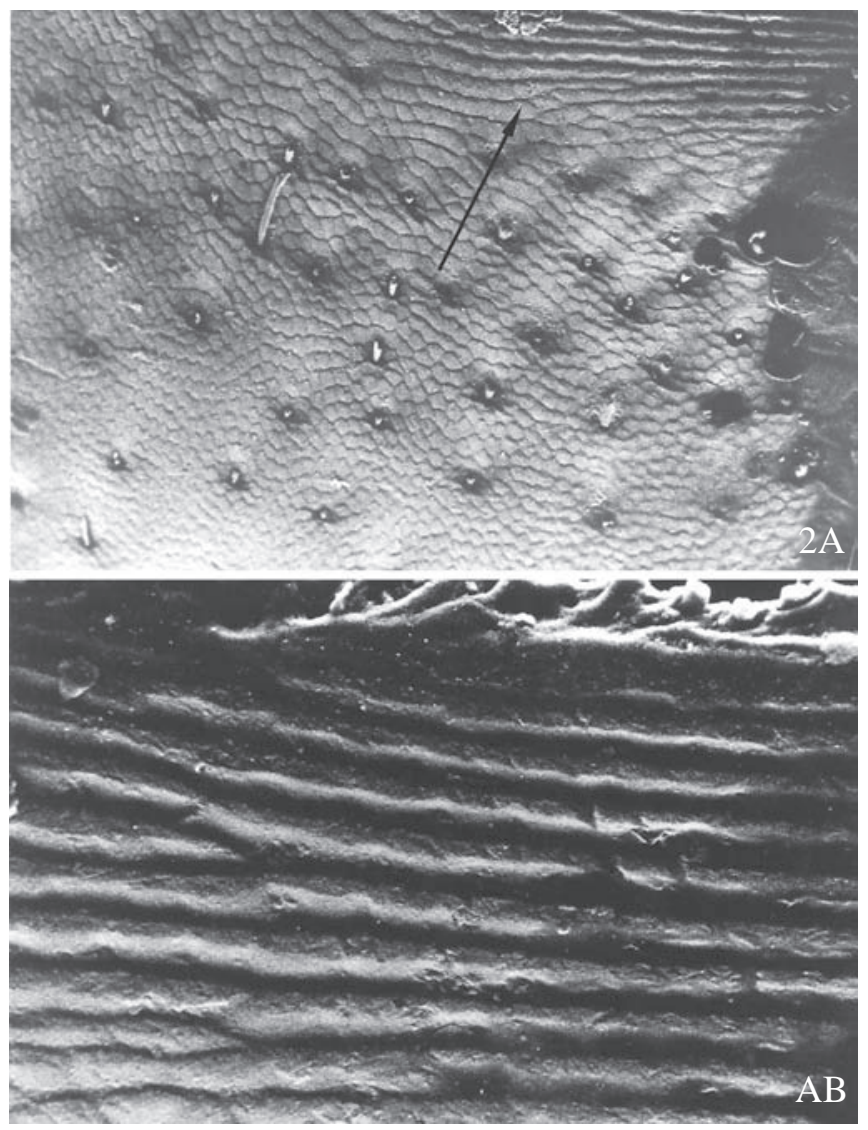

Fig. 2. Bondarius tuberculatus: abdominal tergite 7, striated area at the apex, dorsal view (= plectrum), A) 211,6x; B) 681,8x.

Orchestes) (Coleoptera: Curculionidae). Transactions of the Royal Entomological Society of London 120: 287-296.

Dumortier, B. 1963. Morphology of sound emission apparatus in Arthropoda. p. 273-345. In Busnel, R. G. (ed.). Acoustic behaviour of animals. New York, Elsevier Publ. Co., 933 p.

Gaiger, F. \& S. A. Vanin. 2006. The elytro-femoral stridulatory apparatus in Curculionidae (Coleoptera), with notes on the acoustic behaviour of Arniticus hylobioides (Boheman 1843) and Erodiscus proximus (Viana 1959), and thanatosis display in the latter species. Annales de la Société Entomologique de France (n.s.) 42: 165-170.

Gibson, L. P. 1967. Stridulatory mechanisms and sound production in Conotrachelus (Coleoptera: Curculionidae). Annals of the Entomological Society of America 60: 43-54.

Harman, D. M. \& A. L. Harman. 1972. Stridulatory mechanisms in the white pine weevil, Pissodes strobi. Annals of the Entomological Society of America 65: 1076-1079.

Jansson, A. \& J. Selander. 1977. Sound production associated with mating behaviour of the large pine weevil, Hylobius abietis (Coleoptera: Curculionidae). Annales Entomologici Fennici 43: 66-75.

Lyal, C. H. C. \& T. King. 1996. Elytro-tergal stridulation in weevils (Insecta: Coleoptera: Curculionoidea). Journal of Natural History 30: 703-773.

Mampe, C. D. \& H. H. Neuzing. 1966. Function of the stridulatory organs of Conotrachelus nenuphar (Coleoptera: Curculionidae). Annals of the Entomological Society of America 59: 614-615.

Rosado-Neto, G. H. 1996. Sistemática, análise cladística e distribuição geográfica da tribo Sternechini (Coleoptera, Curculionidae, Molytinae). Doctoral Thesis, Universidade Federal do Paraná, 267 p.

Rosado-Neto, G. H. 2006. Bondarius, um novo gênero da tribo Sternechini (Coleoptera, Curculionidae, Molytinae). Acta Biológica Paranaense 35: $163-169$

Received 06/05/2008; accepted 16/04/2010

Editor: Marcela Laura Monné 